\title{
Serological assays and PCR for detection of Toxoplasma gondii infection in an ostrich farm at Ismailia Province, Egypt
}

\author{
El-Madawy S R ${ }^{1}$; Metawea F $\mathrm{Y}^{2}$ \\ ${ }^{1}$ Department of Parasitology, Faculty of Veterinary Medicine, Benha University, Egypt \\ ${ }^{2}$ Department of Hygiene, Animal behavior and management, Faculty of Veterinary Medicine, Benha
}

University, Egypt

\begin{abstract}
One hundred and twenty serum samples from ostriches (Struthio camelus) in a commercial farm in Egypt were tested for anti-Toxoplasma antibodies using ELISA test (IgM and IgG) and Modified agglutination test (MAT). Five out of 120 birds (4.2\%) were found positive to IgM enzyme immunoassay and 11 birds (9.2\%) were IgG enzyme immunoassay positive. Modified agglutination test detected IgG in 15 birds (12.5\%). PCR amplification of Toxoplasma gondii DNA in the blood of birds was recorded in 9 birds (7.5\%). The Cases were categorized into acute and chronic cases depending on the result of blood-PCR and serological test where the positive cases for IgG were the most frequent (6.7\%). The tissues of five dead birds tested by PCR assay showed the amplification of DNA fragment of $T$. gondii from the heart and brain of two birds, from only the brain of another two birds and from the heart, brain and leg muscles of one bird. The present study concluded that, the chronic cases are the most prevalent among ostriches population and the specific serological tests as MAT alone or with ELISA can be used as a highly sensitive screening test followed by PCR as a confirmatory test for diagnosis of toxoplasmosis and for detection of primary acute and chronic toxoplasmosis in ostriches.
\end{abstract}

Key word: Toxoplasma, Ostriches, ELISA, MAT, PCR, Egypt.

\section{Introduction}

Toxoplasma gondii is a single-celled protozoa that infect several species of warm-blooded animals including birds $(1,2,3$, and 4). Humans can get infection by ingesting of infected meat or ingestion of contaminated food and water with the resistant oocyst form of Toxoplasma excreted by cats (5). Ostriches (Struthio camelus) are large birds that are raised on game farms as nontraditional livestock and have been imported into several developed countries. Meat of ostriches is highly palatable and of low fats. Many authors reported ostriches infection by $T$. gondii $(5,6)$. The most widely used serological test for diagnosis of toxoplasmosis is the ELISA (IgM and IgG) (2). Modified agglutination test (MAT) is considered to be the most sensitive and suitable technique for toxoplasmosis $(7,8,9)$. Moreover, the polymerase chain reaction (PCR) allows detection of parasite DNA; it is highly sensitive, specific and is very useful together with serological tests to differentiate the acute, chronic or reactivated infections $(10,11)$. PCR is also an important diagnostic technique in case of compromised immune system or when antibody titers have not reach threshold levels of detection. In ostriches little is known of $T$. gondii infection in either farmed or wild ratites in Egypt. SO we conducted the present study to detect the infection in the commercial breeding facilities of ostriches by using of two serological tests, ELISA (IgM and IgG) and MAT test, in addition to molecular methods.

\section{1 Farm design}

\section{Materials and Methods}

The present study was carried out in an ostrich farm located at El-Kassaseen, Ismailia province, Egypt. It has about 1500 birds. Ostrich flocks in the farm are divided into groups according to age as follow: 1- 10 days old chicks; 10 - 60 days old, 2-6 months old; 6-12 months old, and over 2 years. The ostrich chicks from day 1 to 10 days old were kept in rearing unit I (environmentally controlled with rubber mat floor). After that, they transferred to rearing unit II \&III (run/pen) with concrete floor until they grew to 2 months and over 2 months to 6 months old respectively. Later on, they were transferred to the grower yard, where ostriches stayed up to 12 months old (when they were ready to be slaughtered) or until 24 months old (when they could replace discarded breeders). The ostriches' drinking water comes from tap water (surface water, Ismailia canal). All ostrich feeds (starter feed (22\%), grower feed (16\%) and breeder feed (20-22\%) protein) were obtained from feed processing company (FPCo) at the $10^{\text {th }}$ of Ramdan city. The ratio of chopped green fodder to feed is maintained at 2:1 for both grower and breeder flocks. The ostrich farm is located 500 meters far from many cultivated lands with fruits and large animal farms (beef calves and dairy buffalos). 


\section{II.2 Ostriches examination}

The clinical signs observed in the farm were anorexia, emaciation, diarrhea, eye affection and death of 5 birds. The dead ostriches were examined at necropsy; tissue samples (brain, heart, breast muscles and leg muscles) were collected from the dead birds and were frozen at $-20 \mathrm{C}$ for molecular analysis. A total of 120 blood samples collected from live birds for serodiagnosis and molecular analysis.

\section{2. 1 Serum samples}

Three $\mathrm{ml}$ of blood was collected from the brachial vein using a disposable syringe of $5 \mathrm{ml}$ size, then transferred to $10 \mathrm{ml}$ sterile serum tube. The blood samples were left to clot and then centrifuged at $3000 \mathrm{rpm}$ for 5 minutes to get the serum. Serum samples were relocated in eppendorf tubes and stored at $4-8{ }^{\circ} \mathrm{c}$ for 24 hrs.

\section{2. 2 Immunassay}

\section{Enzyme-linked immunosorbent assay ( ELISA)}

The presence of specific IgM and $\operatorname{IgG}$ antibodies to $T$. gondii in ostriches was determined by the enzyme-linked immunosorbent assay ( ELISA) using a commercial Toxoplasma IgG and IgM enzyme immunoassay test kits (BioCheck ,Inc) as follow: Ninety-six-well, polystyrene flat-bottomed microtitre plates coated with $T$. gondii antigen were used. Tested sera were diluted at 1:40 in PBS-T and added to the plates after which the plates were incubated at $37^{\circ} \mathrm{c}$ for 30 minutes. After incubation, the plates were washed and flicked five times with diluted wash buffer $(1 \mathrm{X})$. Enzyme conjugate $(100 \mu \mathrm{l})$ was added to each well and mixed gently for 10 seconds and incubated at $37^{\circ} \mathrm{c}$ for 30 minutes. The enzyme conjugate then removed and the well were washed and flicked 5 times with diluted wash buffer $(1 \mathrm{X})$. Afterward, TMB reagent $(100 \mu \mathrm{l})$ was dispensed into each well, mixed gently for 10 seconds and incubated at $37^{\circ} \mathrm{c}$ for 15 minutes. The reaction was stopped by addition $(1 \mathrm{NHcl})$, where mixing occurred for 30 seconds. Plates were read by measuring optical density (OD) at 450nm within 15 minutes with a microwell reader. An OD of 0.901 was considered as the cut-off point.

\section{Modified agglutination test}

Modified agglutination test (MAT) including mercaptoethanol and formalin-fixed whole tachyzoites used to detect only IgG antibodies.The mercaptoethanol used in destroying IgM-like substances that interferes with the test specificity. All ostrich's sera were screened using dilutions of 1:25, 1:50, 1:100, and 1:500, using the modified agglutination test (MAT) as described by Dubey and Desmonts (12). A titer of 1:25 was considered indicative of $T$. gondii $(7,8)$.

\section{2. 3 PCR technique}

Detection of $T$. gondii infection in the blood and tissue samples was determined by nested PCR amplification for the B1 gene (13). Primary amplification had B1F1 primers (5'-CCGTTGGTTCCGCCT CCTTC-3') and B1R1 (5'-GCAAAACAG CGGCAG CGTCT-3') at annealing temperature of $55^{\circ} \mathrm{c}$. In the consequent reaction, the primers B1F2 (5'-CCGCC TCCTTCGTCC GTCGT-3') and B1R2 (5'- GTGGGGG CGGACCTCTCTTG-3') were used at annealing temperature of $60^{\circ} \mathrm{c}$. First step PCR was at $95^{\circ} \mathrm{C}$ for 9 minutes, followed by 35 cycles, each cycle was at $94^{\circ} \mathrm{c}$ for 60 seconds, 30 seconds at the annealing temperature for each pair of primer, and at $72{ }^{\circ} \mathrm{c}$ for 60 seconds. Last cycle was at $72^{\circ} \mathrm{c}$ for 8 minutes. The PCR products were investigated by $1.5 \%$ agarose gel electrophoresis. The PCR amplification yield a product of $213 \mathrm{bp}$ for the $T$. gondii.

\section{Results}

In the current study diagnosis of T.gondii infection in ostriches relied on the clinical signs, immunological studies and molecular studies. The clinical signs were non-specific including anorexia, emaciation, diarrhea, eye affection and deaths (F.g.3). The serological tests show that out of 120 examined ostriches by ELISA, 5 bird (4.2\%) were positive in the IgM enzyme immunoassay, Whilst 11 birds $(9.2 \%)$ were IgG enzyme immunoassay positive (Table. 1). Modified agglutination test (MAT) detects only IgG in 15 birds $(12.5 \%)$ (Table.1). All the positive sera for ELISA (IgG) were positive for MAT which showed high specificity for the detection of anti_Toxoplasma antibodies in comparison to ELISA technique. PCR assay on the blood of ostriches succeeded to detect T.gondii DNA by using B1 gene as a target for amplification in 9 birds (7.5\%) (Fig. 1).

Birds were considered acutely infected when they had only PCR positive or when they had positive $\operatorname{IgM}+$ PCR titres. Chronic infcetion were encountered when birds had only IgG positive, IgG + IgM positive, PCR + IgG positive or PCR + IgM + IgG positive. In the current study positive IgG + PCR (1.7\%) and positive $\operatorname{IgM}+\operatorname{IgG}+$ PCR cases $(3.3 \%)$, positive $\operatorname{IgM}+\operatorname{IgG}(0.8 \%)$, positive PCR only $(2.5 \%)$ and positive $\operatorname{IgG}(6.7 \%)$ were the most frequent cases (Table. 2). Graph (1) clears that the chronic infection was the most prevalent among examined ostriches. 
In dead ostriches, amplification of 213 bp DNA fragment of the expected size of the sequence of B1 gene specific for $T$. gondii had been detected from the heart and brain of two birds, from only the brain of another two birds and from the heart, brain and leg muscles of one bird but no amplification was detected when the breast muscles were tested (Fig. 2 and Table. 3).

\section{Discussion}

Diagnoses of T.gondii infection in ostriches relied on the clinic signs, immunological and molecular studies. The clinical signs were non-specific including anorexia, emaciation, diarrhea, eye affections and deaths. In general, Little is well known about the clinical symptoms of toxoplasmosis in ratites and specifically in ostriches (14).

The applied immunological studies in our study were ELISA (IgM and $\operatorname{IgG}$ ) and MAT (IgG). The number of positive serum samples was higher using MAT test than ELISA test. Concerning this; most authors considered MAT test as the most sensitive $(8,9,12)$. Of the 120 bird sera tested by MAT technique, 15 birds $(12.5 \%)$ were found positive for antibodies of $T$. gondii. ELISA test showed that the prevalence of IgM of T.gondii was $4.2 \%$ and that of IgG was $9.2 \%$. In this respect, antibodies against $T$. gondii were previously detected by modified agglutination test in $1.17 \%$ of ostriches from Spain (15), in $2.9 \%$ of ostriches from Canada (5), in $14.36 \%$ of ostriches from Brazil (14) and in 55.9\% of ostriches from Zimbabwe (6). The variance of the seroprevalence of $T$. gondii in domestic birds within countries may be attributed to the number of examined animals, the methods used for testing, the type of animal hygiene and breeding $(5,16)$. In general, the seroprevalence of $T$. gondii was low in this study, this may be due to the geographical location of the farm which decrease the possibility of infection, the high level of applied biosecurity, in addition to very low density of cats which act as a main infection source in and around the farm.

Although serological testing is considered the main diagnostic technique for toxoplasmosis, it has some limitations because of the false positive results which have been reported by other investigators $(17,18)$, in addition to the false negative results that may happen during the active phase of T.gondii (19). The need for more sensitive techniques as PCR assay and its uses for tissue studies is essential to demonstrate the actual infection in ostriches and to obtain more data on prevalence, frequencies and phases of the parasite. In this study PCR assay detected $T$. gondii DNA in the blood of ostriches by amplification of B1 gene specific to T.gondii and is conserved well among all of the tested strains (13). The infected cases were categorized depending on the result of blood-PCR combined with serological test as acute cases were considered when only PCR was positive or when the bird showed positive titers of IgM + PCR. Moreover chronic cases were that birds had only IgG positive, IgG + PCR positive, IgM + IgG positive, or IgM + IgG + PCR positive (20). In our study the chronic infection was the most prevalent as IGg positive cases was the most frequent $(6.7 \%)$.

In different tissues of ostriches amplification of $\mathrm{B} 1$ gene of $T$. gondii was detected from 5 dead birds in brain, heart, breast and leg muscles. In this respect, no available literatures were found but the distribution $T$. gondii in the tissue of the heart, brain, and pectoral muscle of chicken was recorded (21).

\section{Conclusion}

The present study is the first time to adopt PCR and serology of $T$. gondii antibodies in ostriches in Egypt and suggests the probability of acquiring toxoplasmosis from ostriches as a food source where the chronic cases are the most prevalent among ostriches population. The specific serological tests as MAT alone or with ELISA can be used as a highly sensitive screening test followed by PCR as a confirmatory test for diagnosis of toxoplasmosis and for detection primary acute and chronic toxoplasmosis in ostriches. Because the ingestion of oocysts from cat feces is an important route of Toxoplasma infection, Future researches should be addressed to detect the method of ostrich infection by $T$. gondii which may be due to the access of cat to ostrich farm, contamination of birds food by cat feces during manufacturing, transportation and storage, water contamination or any other possible sources.

\section{Reference}

[1] J.P. Dubey and C.P. Beattie, Toxoplasmosis of Animals and Man. CRC Press, Boca Raton, FL, 1988, 220 pp.

[2] J.P. Dubey, M.E. Camargo, M.D. Ruff, S.K. Shen, G.L. Wilkins, O.C.H. Kwok and P. Thulliez, 1993. Experimental toxoplasmosis in turkeys, Journal of Parasitology, 79, 1993, 949-952.

[3] J.P. Dubey, M. A. Goodwin, M.D. Ruff, O.C.H. Kwok, S. K. Shen, G. L. Wilkins and P. Thulliez, Experimental toxoplasmosis in Japanese quail, Journal of Veterinary Diagnostic Investigation, 6 (2), 1994, 216- 221

[4] J.P. Dubey, M.D. Ruff, M.E. Camargo, S.K. Shen, O.C.H. Kwok, G.L. Wilkins and P. Thulliez, Experimental toxoplasmosis in Bob-white quail (Colinus virginianus), Journal of Parasitology, 79, (6), 1993, 935-939.

[5] J. P. Dubey, W. B Scandrett, O. C H. Kwok, and A. A. Gajadhar, Prevalence of Antibodies to T. gondii in Ostriches (Struthio camelus), Journal of Parasitology, 86 (3), 2000, 623-624

[6] T. Hove and S. Mukaratirwa, Seroprevalence of T. gondii in farm-reared ostriches and wild game species from Zimbabwe, Acta Tropica, 94 (1), 2005, 49-53

[7] J.P. Dubey, Validation of the specificity of the modified agglutination test for toxoplasmosis in pigs, Veterinary Parasitology, 71 (4), 1997, 307-310 
[8] J.P. Dubey, P. Thulliez, R.M. Weigel, C.D. Andrews, P. Lind \& E.C. Powell, Sensitivity and specificity of various serologic tests for detection of T. gondii infection in naturally infected sows, American Journal of Veterinary Research, 56, (8), 1995, 10301036 .

[9] A. El-Massey, O.A. Mahdy, A. El-Ghaysh and J.P. Dubey, Prevalence of T. gondii antibodies in sera of turkeys, chickens, and ducks from Egypt, Journal of Parasitology, 86, (3), 2000, 627-628.

[10] S. O' Neil and M. Lappin, Clinical and Epidemiological aspects of FIV and Toxoplasma coinfections, Journal of the American Animal Hospital Association, 27 (211), 1991, article 211.

[11] K. Switaj, A. Master, M. Skrzypczak and P. Zaborowski, Recent trends in molecular diagnostics forT. gondii infections, Clinical Microbiology and Infection, 11 (3), 2005, 170-176.

[12] J.P. Dubey, and G. DesmontS, Serologic responses of equids fed with T. gondii oocysts. Equine, Veterinary Journal, 19 (4), 1987, $337-339$.

[13] J.L. Burg, C.M Grover, P. Pouletty and J.C. Boothroyd, Direct and sensitive detection of pathogenic protozoan T. gondii, by polymerase chain reaction, Journal of Clinical Microbiology 27 (8), 1989, 1787- 1792.

[14] A.P.A. Contente, P.F. Domingues and R.C. Silva, Prevalence of T. gondii antibodies in-ostriches (Struthio camelus) from commercial breeding facilities in the state of São Paulo, Brazil, Brasilian Journal of Veterinary Research and Animal Science, 46, 2009, 175-180.

[15] R.A. Martínez-Díaz, B. Simmons and F. Ponee-Gordo, Serologic screening to detect T. gondii antibodies in farmed ostriches (Struthio camelus) in Spain, Revista Ibérica de Parasitología, 62 (3-4) , 2002, 69-71.

[16] S.E. Orosz, J.D. Mullins and S. Patton, Evidence for toxoplasmosis in two ratites, Joumal of the Association of Avian Veterinarians, 6 (4), 1992, 219-222.

[17] W. T. Hofgartner, S. R. Swanzy, R. M., Bacina, J., Condon, M., Gupta, P. E. Matlock, D. L. Bergeron, J. J. Plorde \&T. R. Fritsche, Detection of immunoglobulin $\mathrm{G}$ (IgG) and $\mathrm{IgM}$ antibodies to T. gondii: Evaluation of four commercial immunoassay systems, Journal of Clinical Microbiology, 35, (12),1997 3313-3315.

[18] M. Wilson, J.S. Remington, C. Clavet, G.Varney, C. Press and D. Ware, Evaluation of six commercial kits for the detection of human immunoglobulin $\mathrm{M}$ antibodies to $\mathrm{T}$. gondii. The FDA toxoplasmosis ad hoc working group, Journal of Clinical Microbiology, 35 (12), 1997, 3112-3115

[19] P.Y. Lee, J. Mangan, R.E. Holliman and P.D. Butcher, Quantitation of Toxoplasma gondii DNA in a competitive nested polymerase chain reaction, Journal of clinical Pathology, 52 (1), 1999, 61-64.

[20] J. V. Castillo- Morales, Y. K. Acosta Viana, S. E. Guzm’an-Mar, M. Jim’enez-Coello, C.J. Segura-Correa, A. J. Aguilar-Caballero and A. Ortega-Pacheco, Prevalence and Risk Factors of T. gondii Infection in Domestic Cats from the Tropics of Mexico Using Serological and Molecular Tests, Interdisciplinary Perspectives on Infectious Diseases, Volume 2012, Article ID 529108, ,2012, 6pages doi:10.1155/2012/529108.

[21] J. P. Dubey, S. Karhemere, E. Dahl, C. Sreekumar, A. Diabate, K.R. Dabire, M.Vianna, C. B., Kwok, O. C. H and T. Lehmann, First biologic and genetic characterization of T. gondii isolates from chickens from Africa (Democratic Republic of Congo, Mali, Burkina Faso, and Kenya), Journal of Parasitology, 91 (1), 2005, 69-72

Table. 1: Incidence of T. gondii among examined ostriches using serological and PCR tests

\begin{tabular}{ccc}
\hline Tests & $\begin{array}{c}\text { No. of Positive } \\
\text { hirds/120 }\end{array}$ & $\%$ \\
\hline IgM (ELISA) & 5 & 4.2 \\
IgG (ELISA) & 11 & 9.2 \\
IgG (MAT) & 15 & 12.5 \\
PCR & 9 & 7.5 \\
\hline
\end{tabular}

Table. 2: Phases and frequency of $T$. gondii infection in ostriches according to serological and PCR results

\begin{tabular}{cccc} 
Tests & No. of positive birds/ 120 & $\%$ & Phases \\
\hline IgG only & 8 & 6.7 & Chronic \\
IgM + IgG & 1 & 0.8 & Chronic \\
IgG +PCR & 2 & 1.7 & Chronic \\
IgM+IgG+PCR & 4 & & Chronic \\
PCR only & 3 & 3.3 & acute \\
\hline
\end{tabular}


Table. 3: Distribution of Toxoplasma in the tissue of dead ostriches using PCR

\begin{tabular}{ccccc}
\hline $\begin{array}{c}\text { Examined } \\
\text { birds }\end{array}$ & Heart & Brain & Leg Muscles & Breast \\
Muscles \\
\hline $1^{\text {st }}$ bird & + ve & + ve & ND & ND \\
$2^{\text {nd }}$ bird & ND & $+v e$ & ND & ND \\
$3^{\text {rd } b i r d ~}$ & + ve & + ve & $+v e$ & ND \\
$4^{\text {th }}$ bird & + ve & $+v e$ & ND & ND \\
$5^{\text {th }}$ bird & ND & $+v e$ & ND & ND \\
\hline
\end{tabular}

ND: not detected

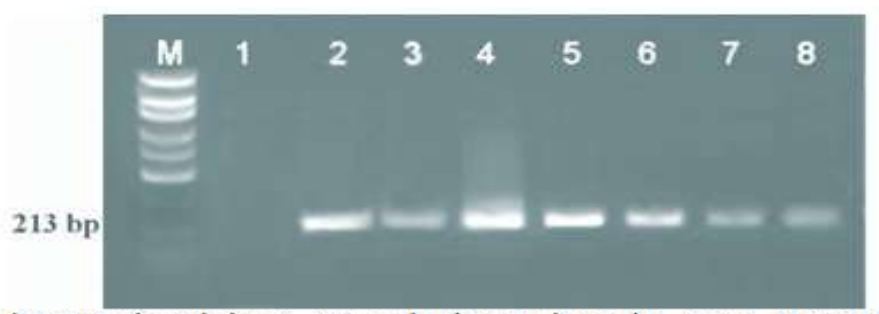

Fig. 1. Amplified product analyzed by $1.5 \%$ gel electrophoresis. Lane 1: negative blood sample for Toxoplasma, Lane: $2,3,5,6,7,8$ positive amplification. Lane 4: positive control samples. Lane $\mathrm{M}$ molecular weight marker $100 \mathrm{bp}$.

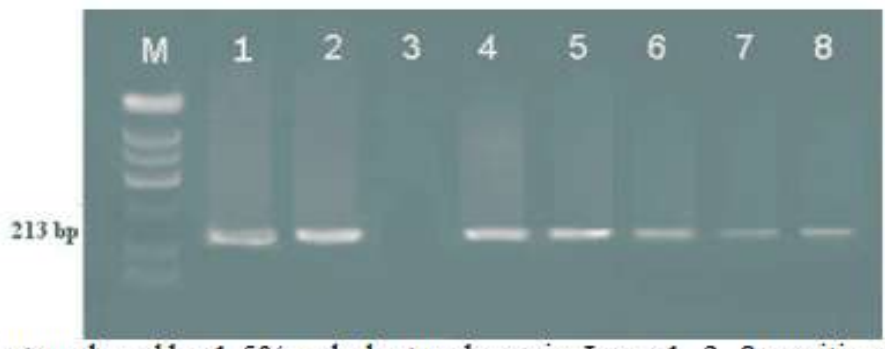

Fig. 2. Amplified product analyzed by $1.5 \%$ gel electrophoresis. Lane 1, 2, 8 positive amplification of brain, Lane 3 negative amplification from breast muscles, Lane 4,5,6 positive amplification from heart, Lane 7 Positive amplification from leg muscles, Lane $\mathrm{M}$ molecular weight marker $100 \mathrm{bp}$
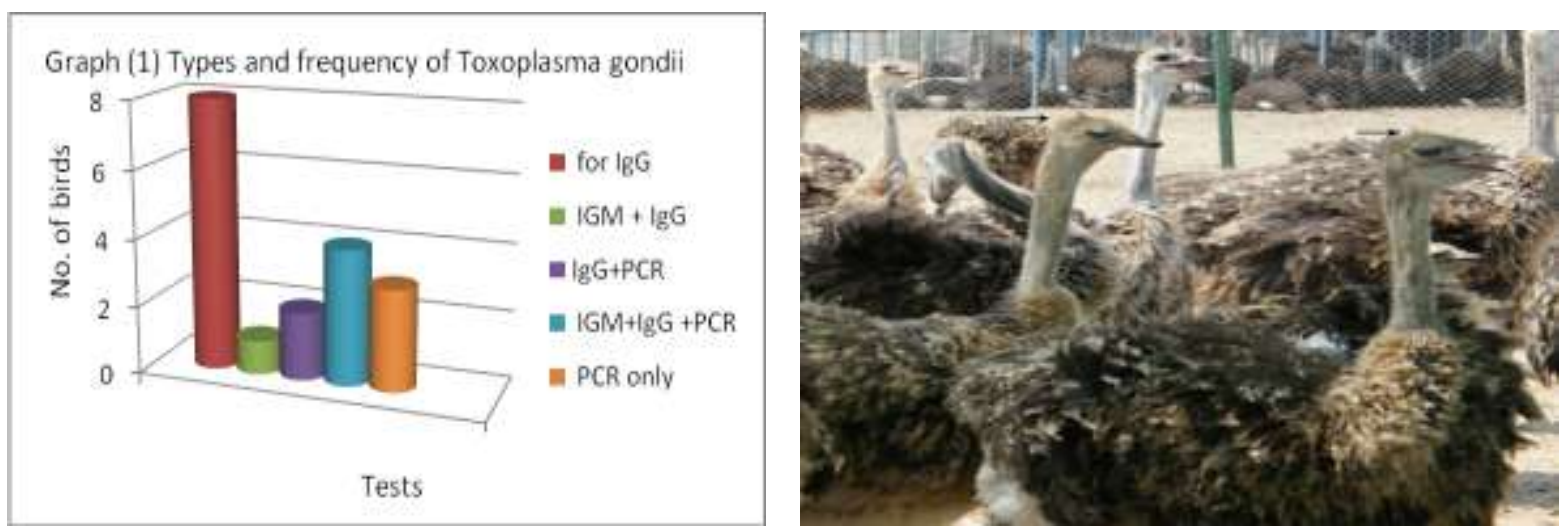

Fig. 3 Some ostriches showing eye affections (arrows) 